\title{
Illuminating Leonardo
}

\author{
A Festschrift for Carlo Pedretti \\ Celebrating His 70 Years of Scholarship \\ (1944-2014)
}

Edited by

Constance Moffatt

Sara Taglialagamba

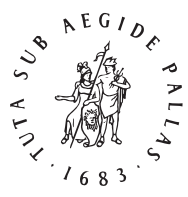

B R I L L

LEIDEN | BOSTON 


\section{Contents}

Preface: "Poni il vero mezzo..." IX

Constance Moffatt

Preface: "Masso Miglio Ala Formica" XI

Sara Taglialagamba

List of Figures XII

Introduction 1

Constance Moffatt and Sara Taglialagamba

\section{PART 1}

Books and Influence

$1 \quad$ One for the Books: A Bibliographical 'Gleaning' for CP 9 Max Marmor

2 The Codex Corazza and Zaccolini's Treatises in the Project of Cassiano dal Pozzo for the Spreading of Leonardo's Works 19

Alfredo Buccaro

3 A Copy of Sacrobosco's Sphaera in Mirror Script Attributed to Matteo Zaccolini 33

Domenico Laurenza

PART 2

Dissemination of Knowledge

4 A Short Note on Artisanal Epistemology in Leonardo's Treatise on

Painting 51

Claire Farago

$5 \quad$ Leonardo's Cartonetti for Luca Pacioli's Platonic Bodies 69

Pietro C. Marani

PART 3

Architecture

6 Giuliano da Sangallo and Leonardo da Vinci: Cross-Pollination or Parallels? 85

Sabine Frommel 
$7 \quad$ Evidence of Leonardo's Systematic Design Process for Palaces and Canals in Romorantin 100 Matthew Landrus

8 Vitruvius in the Trattato dell'Architettura by Luca Pacioli 114 Francesco Di Teodoro

$9 \quad$ Notes on Leonardo and Vitruvius 120

Richard Schofield

PART 4

Painting and Drawing

10 Why Did Leonardo Not Finish the Adoration of the Magi? 137

Francesca Fiorani

11 "Here's Looking at You”: The Cartoon for the So-called 'Nude Mona Lisa' 151

Martin Kemp

12 Leonardo da Vinci's Mona Lisa: A Portrait without a

Commissioner? 169

Joanna Woods-Marsden

13 Leonardo's Followers in Lombardy: Girolamo and Giovan Ambrogio Figino 183

Annalisa Perissa Torrini

\section{PART 5}

\section{Machines}

14 A Machine to "Build" Artilleries 201

Andrea Bernardoni

15 Bombards and Noisy Bullets

Pietro Monte and Leonardo da Vinci's Collaboration 210 Pascal Brioist

16 Leonardo and the artes mechanicae 215

Romano Nanni

PART 6

Sculpture

17 "The Sculptor Says"

Leonardo and Gian Cristoforo Romano 223

Carlo Vecce 
18 Leonardo and the Trivulzio Monument: Some Questions and

Evidence (1507-1518) 239

Marino Viganò

PART 7

Science and Nature: The Body, the Body of the Earth

19 The Midpoint of the Human Body in Leonardo's Drawings and in the Codex Huygens 259

Paola Salvi

20 Drawing Bridges: Leonardo da Vinci on Mastering Nature 285 Leslie Geddes

21 Leonardo da Vinci's Hydraulic Systems and Fountains for His French Patrons Louis XII, Charles d'Amboise and Francis I

Models, Influences, and Reprises Featured in the Art of Garden

Design 300

Sara Taglialagamba

22 Pyramids, Rays, Points, and "Spiritual Powers": Leonardo's Research during the Last Decade of the Fifteenth Century 315

Fabio Frosini

23 A Hydraulic System Drawing by Leonardo: Some Evaluations 329

Damiano Iacobone

24 Leonardo's Maps 342

Constance Moffatt

25 Sightings, Mistakes and Discoveries “al verso” 359

Alessandro Vezzosi

Essential Bibliography $\quad 367$

Index 380 


\title{
Leonardo's Cartonetti for Luca Pacioli's Platonic Bodies
}

\author{
Pietro C. Marani \\ Politecnico di Milano, Dipartimento di Design
}

The drawings of the sixty regular bodies that illustrate De divina proportione by Luca Pacioli in the parchment version in the Biblioteca Ambrosiana, marked S.P. 6 (previously Cod. F 170 sup.), have been studied extensively. ${ }^{1}$ In De viribus quantitatis, Luca Pacioli recalls the graphic models executed by Leonardo's "ineffabile senistra mano" ... "in detto libro ... qual ancora apresso di noi tenemo maravigliosi a ognuno che li mirano." The work was destined for Galeazzo Sanseverino, Pacioli's "peculiare patrone," before passing into the hands of Galeazzo Arconati (later donated to the Ambrosiana in 1637 along with Leonardo's famous manuscripts of which only the Codex Atlanticus is still in Milan, the others now being at the Institut de France in Paris). One could surmise that Pacioli did not mean that he possessed the book (despite the fact that the usage of the singular "qual" would lead us to believe this), since once finished it necessarily would have been handed over to Sanseverino. He refers instead to Leonardo's preparatory drawings, today believed to be dispersed. ${ }^{2}$ However,

1 See Alessandro Rovetta, "I dipinti di Leonardo e dei leonardeschi," in L'Ambrosiana e Leonardo, exh. cat., Milan, Biblioteca-Pinacoteca Ambrosiana, 1 December 1998-30 April 1999, ed. Pietro C. Marani, Marco Rossi, Alessandro Rovetta (Novara: Interlinea, 1998), 134-139 (previous bibliography). There also exists a very good facsimile of De divina proportione in the Ambrosiana Library: Luca Pacioli. De divina proportione, introduction by Augusto Marinoni, "Fontes Ambrosiani in lucem editi cvra et stvdio Bibliothecae Ambrosianae," LXXII (Milan: Silvana Editoriale, 1982). Although of great use in the study of the illustrations, the following considerations are based on direct examination of the original by myself (along with the drawings of Leonardo's Codex Atlanticus which will later be mentioned) on 16 September 2013. I would like to express my sincerest thanks to Franco Buzzi, Marco Navoni, Elena Fontana, Elisa Mantia, and all the staff at the Biblioteca Ambrosiana for the kindness and assistance shown to me, and to Christian Bayliss for the translation of my text.

2 Marinoni, in the accompanying booklet to the facsimile edition (see n. 1 ) also sustains that (p. 14) Pacioli kept for himself Leonardo's original drawings, stating however that "nell'impossibilità di confrontare gli originali con queste copie è legittimo ritenere che la differenza sul piano estetico sia notevole," and adding that "Noi non sappiamo se Leonardo numerò i suoi disegni originali. Conoscendo le sue abitudini siamo quasi sicuri che egli lavorasse su fogli ancora sciolti, seguendo l'ordine del testo ...." For quotation of Leonardo's 
the illustrations in the Ambrosian Codex are considered to be "the best copy of the original Vinci works" even though "the appearance of several of the sheets indicate considerable and direct intervention by Leonardo, especially in the drawing,"3 as confirmed by Martin Kemp. ${ }^{4}$ The almost picturelike, exceptionally fine finish of some of the bodies in the Ambrosiana copy, especially when compared to the lack of quality in others, point unequivocally to Leonardo at least concerning a part of the tables that bear evidence of very fine left-handed strokes in the shaded areas, for example, the bodies drawn on tables VIIII, XI, XV, XVIII, XX-XXII, XXIX, XXX, and XXXV, on ff. $95 \mathrm{v}, 96 \mathrm{v}, 98 \mathrm{v}, 100 \mathrm{v}, 101 \mathrm{r}, 101 \mathrm{v}$, $102 \mathrm{r}, 106 \mathrm{v}, 107 \mathrm{r}$, and $108 \mathrm{v}$, with beautiful drawings also on ff. $107 \mathrm{~V}, 108 \mathrm{r}, 109 \mathrm{~V}$, and $110 \mathrm{r}$. The many remaining drawings of the Ambrosiana manuscript are less refined than are those in the other known versions of the De divina proportione, kept at the Bibliothèque de Genève with the mark Ms. Langues Etrangères 210. They are more flowing and almost monochrome, except for some prisms painted in violet, ${ }^{5}$ even though the amanuensis of the text in the Geneva Codex is the same as the Milanese: the copyist Giovanni Battista Lorenzi, who will soon be the subject of an exhibition in the Biblioteca Trivulziana at the Castello Sforzesco. ${ }^{6}$ I do not intend either to deal with problems related to the interpretation of the platonic bodies in this essay or to solve once and for all the problem of the authorship of the plates in the Ambrosian Codex. It seems prudent, however, to analyze the way Leonardo (and his assistants) transposed his drawings in at least three illustrated versions of the De divina proportione (as well as the two in Milan and Geneva; the third, the original destined for Ludovico il Moro, has yet to be found) and in a printed version published in Ven-

drawings in Pacioli's De viribus quantitatis see: Luca Pacioli. De viribus quantitatis, Trascrizione di Maria Garlaschi Peyrani dal Codice n. 250 della Biblioteca Universitaria di Bologna, Prefazione e direzione di Augusto Marinoni (Milan: Ente Raccolta Vinciana, 1997), 305.

3 Rovetta, I dipinti di Leonardo, 138 (my translation).

4 Cf. Martin Kemp, The Science of Art: Optical Themes in Western Art from Brunelleschi to Seurat (New Haven and London: Yale University Press, 1990), 171 (Italian ed.: La scienza dell'arte: Prospettiva e percezione visiva da Brunelleschi a Seurat (Florence: Giunti, 1994), 191.

5 I have not however examined the original version of the Geneva Codex, of which there exists a recent and excellent facsimile just published by Aboca Museum Edizioni, Borgo San Sepolcro, 2010. This facsimile is accompanied by the volume Antologia della Divina Proporzione di Luca Pacioli, Piero della Francesca e Leonardo da Vinci, ed. Duilio Contini, Piergiorgio Odifreddi, Antonio Pieretti (Aboca: Borgo San Sepolcro, 2010), with a collection of essays also previously published (like the afore-mentioned one by A. Marinoni in n. 1, C. Quattrini and others). I have examined the facsimile in the version kept at the Biblioteca Trivulziana, with thanks to Isabella Fiorentini.

6 Il libro manoscritto tra miniatura e scrittura nella Milano di Leonardo da Vinci: Il copista Giovanni Battista Lorenzi, Biblioteca Trivulziana, ed. I. Fiorentini, forthcoming. 
ice in 1509 in which there are the same illustrations with the same numbers that characterize the platonic bodies in the manuscript versions. ${ }^{7}$

To honor Carlo Pedretti and his style of inquiry, I consider the following question: How was it possible to 'produce' at least three manuscript versions (and one printed version), all accompanied by drawings that were specially created each time, based on (now lost) Leonardo originals? We can make the most here of recent studies on the way Leonardo (and his assistants) transposed his models by means of cartoni and cartonetti to enable the creation of finished paintings and a certain amount of copies on one hand and, on the other hand, the opportunity to duplicate, vary, and correct an original graphic layout, not only in the case of "artistic" compositions but also in the case of "scientific" drawings and, especially, anatomical and perspective ones. ${ }^{8}$ For this latter genre of illustration-anatomical and perspective-classic examples are the anatomical drawing of Windsor RL $12281 \mathrm{r}$ and the study of the mazzocchio in the Codex Atlanticus f . $263 \mathrm{v}$-b [710 b r], where the technique of piercing the sheet was used not only to duplicate and transfer the drawings onto other supports, but also to correct initial layouts and to achieve exact symmetry in the two halves of the image. ${ }^{9}$

In light of this technique, a new examination of two drawings in the Codex Atlanticus proves informative. The drawings on f. 263 r-c [708 r] (Fig. 5.1) and f. 263 r-b [707 r] (Fig. 5.2), the only two surviving from a larger series that included a further fifty-eight models, depict an icosidodecahedron, both solid and "hollow," like those featured in tables XXIX and XXX of De divina proportione by Luca Pacioli, and as such present in f. $105 \mathrm{v}$ (Fig. 5.3) and f. $106 \mathrm{r}$ (Fig.

7 See Luca Pacioli, Divina proportione ... (Venezia: Paganius Paganinus, 1509). I consulted the edition in the possession of the Biblioteca dell'Ente Raccolta Vinciana di Milano.

8 Concerning Leonardo's cartoons in general, see Carmen C. Bambach, Drawing and Painting in the Italian Renaissance Workshop: Theory and Practice, 1300-1600 (Cambridge: Cambridge University Press, 1999), 23, 91, 111-114, 263, 277ff., is fundamental. See also, in particular for the Isabella d'Este cartoon at the Louvre: Francis Ames Lewis, Isabella and Leonardo: The Artistic Relationship between Isabella d'Este and Leonardo da Vinci, 1500-1506 (New Haven and London: Yale University Press, 2012), 130-135; Pietro C. Marani, "Cartone e disegno sottostante: Il problema dell'originalità dell'underdrawing nei dipinti leonardeschi e una proposta per la copia della Gioconda al Prado," in Between Art and Science: A Volume in honor of Martin Kemp, ed. Juliana Barone, Matthew Landrus (forthcoming).

9 Concerning these drawings see Pietro C. Marani, "Lo 'spolvero' dei cartoni e dei disegni di Leonardo: Nuove evidenze per la duplicazione, la seriazione e la correzione delle immagini," in Studi in onore di Maria Grazia Albertini Ottolenghi, eds. Marco Rossi, Alessandro Rovetta, Francesco Tedeschi (Milan: Vita e Pensiero-Università Cattolica del Sacro Cuore, 2013), 99-108. 


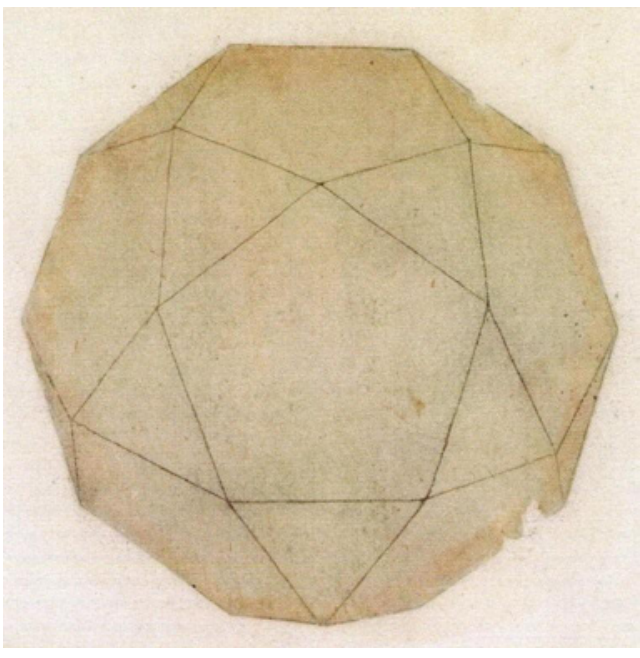

FIGURE 5.1

Assistant to Leonardo (Luca Pacioli?), Icosidodecaedro. Milan, Biblioteca Ambrosiana, Codex Atlanticus, $f .263$ r-c [7o8r] (upside down).

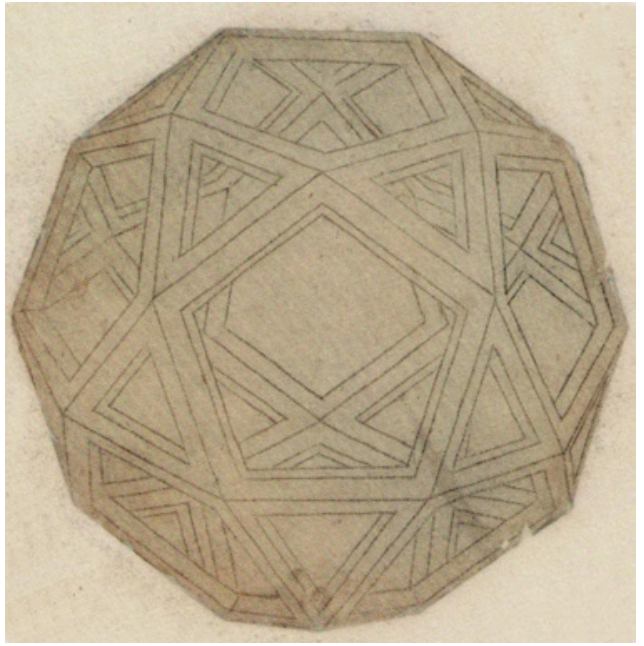

FIGURE 5.2

Assistant to Leonardo (Luca Pacioli?), Icosidodecaedro vacuus. Milan, Biblioteca Ambrosiana, Codex Atlanticus, f. $263 r$ - $b[707 r]$ (turned 45 degrees).

5.4) of the Ambrosiana version and in f. 89 r (Fig. 5.5) and f. $90 \mathrm{r}$ (Fig. 5.6) of the Geneva version, as well as in the corresponding tables XXIX and XXX of the printed version. The two drawings of the Codex Atlanticus have been analyzed by but a handful of scholars, including Carlo Pedretti, who believes the drawings were not by Leonardo, but "probably a copy of one of Leonardo's illustrations to Pacioli's Divina proportione."10 Carmen C. Bambach also considers

$10 \quad$ See Carlo Pedretti, The Codex Atlanticus of Leonardo da Vinci: A Catalogue of Its Newly Restored Sheets, Part Two, Volumes VII-XII (New York: Johnson Reprint Corporation- 


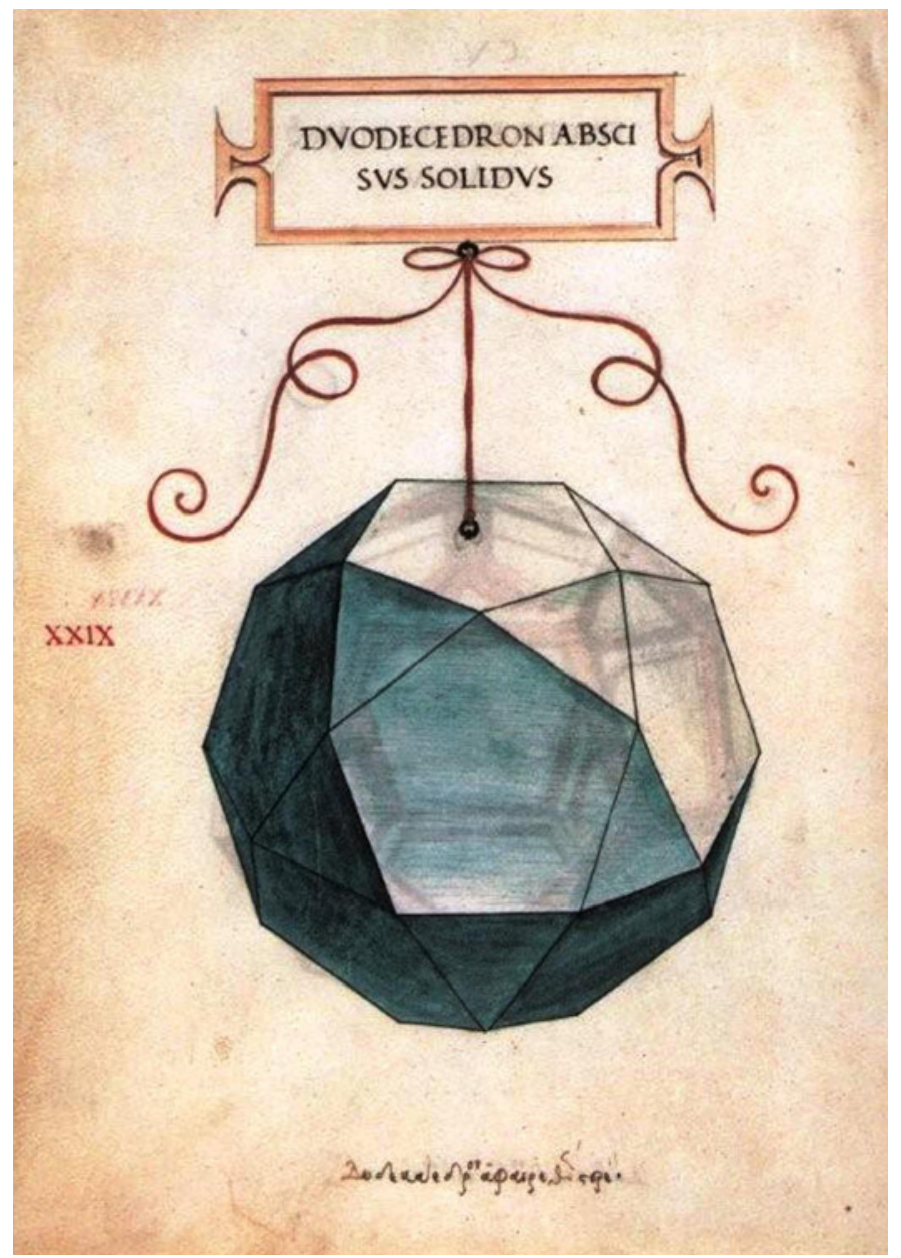

FIGURE 5.3 Leonardo da Vinci and assistant, Icosidodecaedro abscisus solidus, in Luca Pacioli, De divina proportione, f. 105 v. Milan, Biblioteca Ambrosiana, inv. S.P. 6 (ex Cod. F 170 sup).

Harcourt Brace Jovanovich, 1979), 82. Augusto Marinoni, in his edition of the Codex Atlanticus (1975-1980) did not express himself on the originality of the drawings, considering them originals. See now Leonardo da Vinci. Il Codice Atlantico della Biblioteca Ambrosiana di Milano, nella trascrizione critica di Augusto Marinoni, presentazione di Carlo Pedretti, Tomo II (Volumi v-VIII) (Florence: Giunti, 2000), 1388-1389. See also Carmen C. Bambach, "Pounced Drawings in the Codex Atlanticus," Achademia Leonardi Vinci, 3 (1990), 129-131, who lists all Leonardo's pounced drawings in the Codex Atlanticus: f. $263 \mathrm{r}-\mathrm{b}[707 \mathrm{r}]$ is considered to be a "copy after Leonardo," and f. $263 \mathrm{r}-\mathrm{c}$ [708 r] is only 


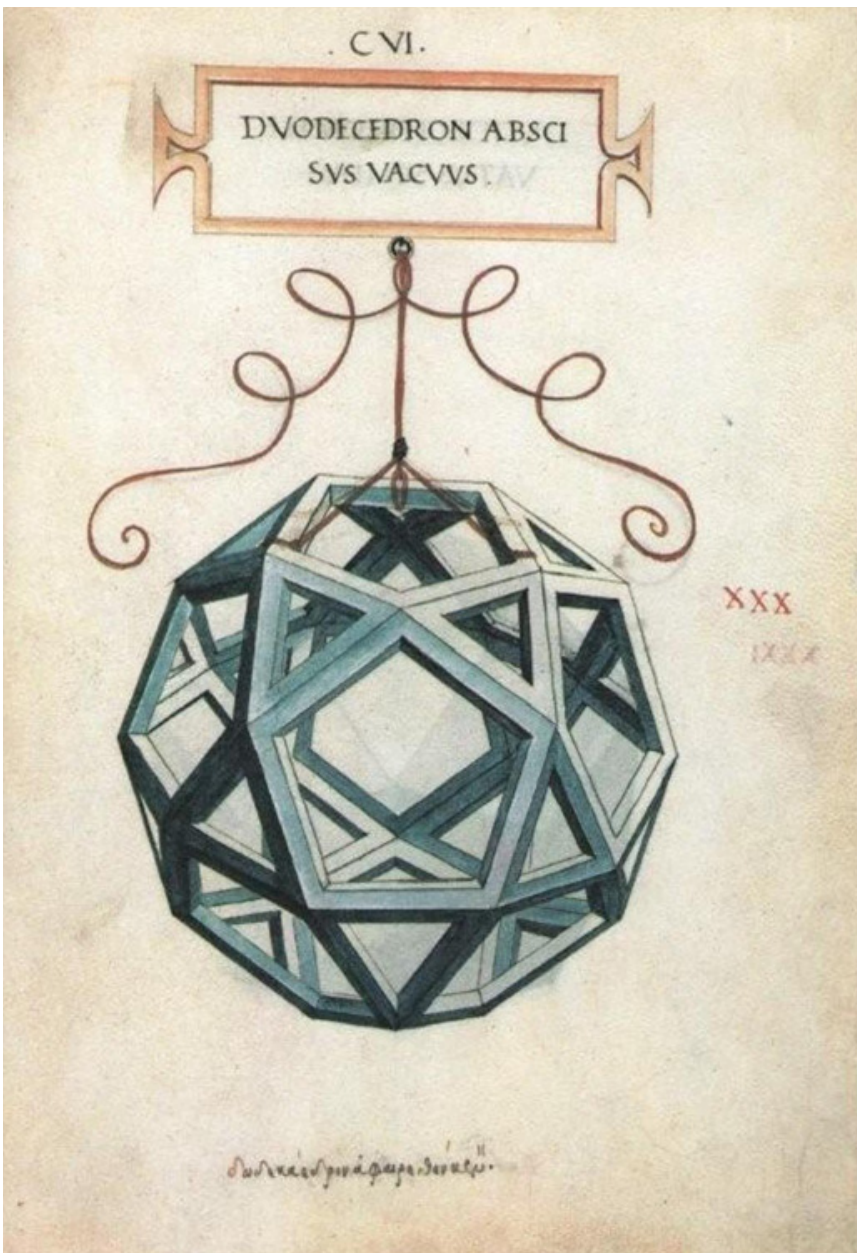

FIGURE 5.4 Leonardo da Vinci and assistant, Icosidodecaedro abscisus vacuus, in Luca Pacioli, De divina proportione, $f .106 r$. Milan, Biblioteca Ambrosiana, inv. S.P. 6 (ex Cod. F 170 sup).

labeled "not by Leonardo." See also Carmen C. Bambach,"Leonardo, Tagliente, and Duerer: 'La scienza del far di groppi," Achademia Leonardi Vinci 4 (1991), esp. 79-81, for Leonardo's practice of drawing and pricking. On these two ff. $263 \mathrm{r}-\mathrm{b}$ [707 r] and $263 \mathrm{r}-\mathrm{c}$ [708 r] of the Codex Atlanticus, see Marco Versiero, Codex Atlanticus: Leonardo, la politica e le allegorie: Disegni di Leonardo dal Codice Atlantico, exh. cat., Milan, Biblioteca Ambrosiana, n. 04 (Novara: De Agostini, 2010), 142-145, cat. nn. 38 and 39, who considers them "non di mano di Leonardo." 


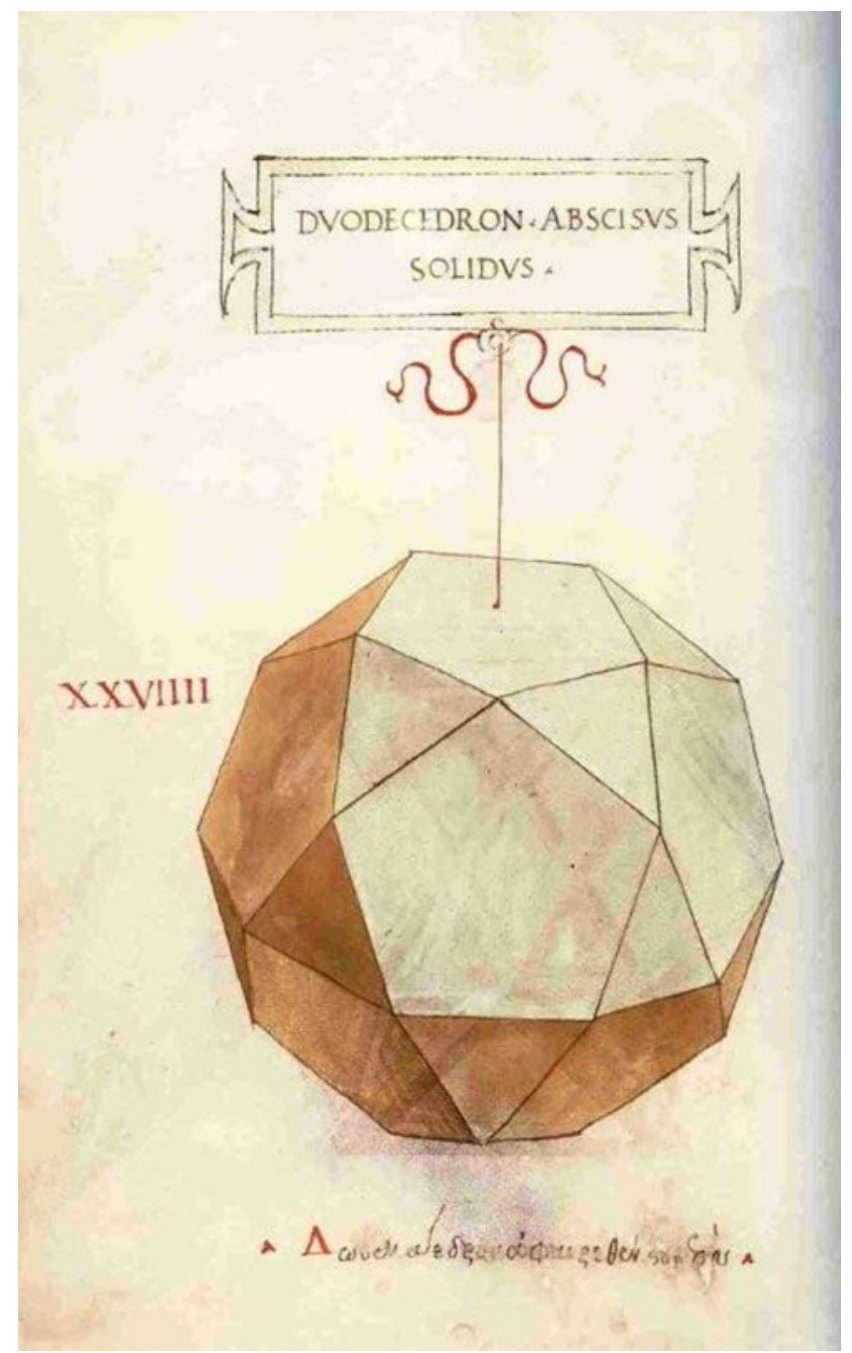

FIGURE 5.5 Unknown artist, Icosidodecaedro abscisus solidus, in Luca Pacioli, De divina proportione, f. 89 r. Geneva, Bibliothèque, inv. Langues Etrangères 210.

them to be "probably later copies by a pupil, rather than originals by Leonardo," stating that they "resemble Fra Luca Pacioli's woodcuts in De divina proportione (based on Leonardo's drawings)." affixed to f. 263 r-b [707 r] has been mounted on the support of the Codex 


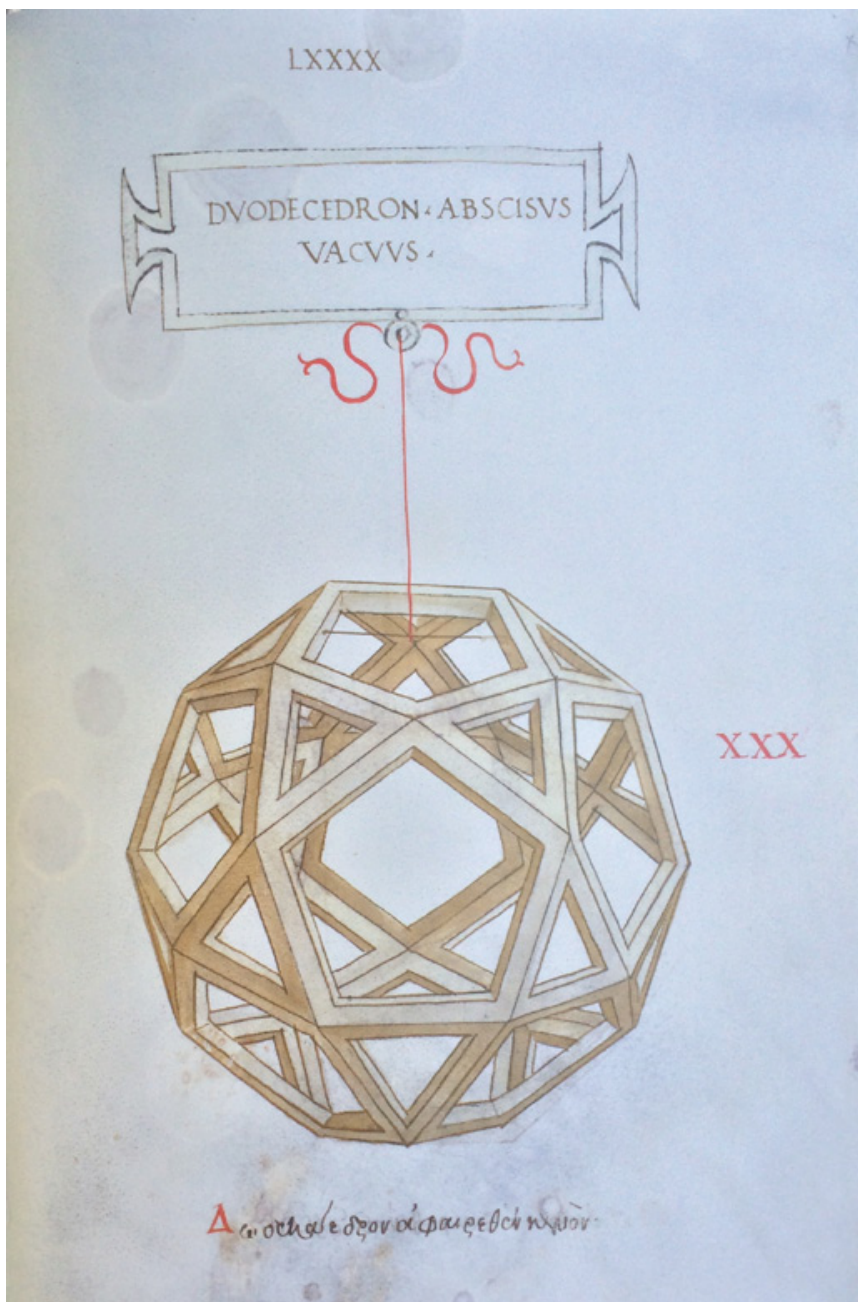

FIGURE 5.6 Unknown artist, Icosidodecaedro abscisus vacuus. In Luca Pacioli, De divina proportione, f. 9 o r. Geneva, Bibliothèque, inv. Langues Etrangères 210.

Atlanticus rotated to approximately 45 degrees, and since the one depicted on f. $263 \mathrm{r}-\mathrm{c}[708 \mathrm{r}]$ has been mounted over it, these two drawings were not immediately connected by Pedretti, Bambach, or Versiero (or even by Marinoni) to tables XXX and XXIX of De divina proportione. However, it is beyond any shadow of a doubt that it is to the polyhedron numbered xxx that f. $263 \mathrm{r}-\mathrm{b}[707 \mathrm{r}]$ is connected (as shown by the reproduction seen in fig. 2 ), positioned correctly after its 45 -degree rotation). Similarly, once turned, the relationship between 
the drawing of the Codex Atlanticus f. 263 r-c [708 r] and that of table xxix by Pacioli becomes even more evident.

A careful analysis of the execution and size of these two drawings in the Codex Atlanticus has enabled us to clarify the practices of Leonardo's workshop at the very moment when it was called on to collaborate with the maestro in preparing of a series of graphic instruments and duplicates to use in drafting the various manuscripts and prints of Pacioli's work.

Moreover, the two drawings of the Codex Atlanticus, executed in ink, both bear evidence of dust dots along the lines that define the edges of the two bodies, unequivocal evidence that they were taken from previous original drawings by Leonardo, as Carlo Pedretti suggests, even though they might not be classified as simple copies. In order to be more precise, we could state that they would appear to constitute the cartoons (cartoni) or counter-cartoons of the original drawings. Indeed, they were not pricked in order to be directly transferred onto the parchment of the two surviving codices, but were most likely needed in order to preserve the memory of the originals that were used and, most probably, spoiled on account of the pouncing dust or to create a duplicate that could have been re-traced transparently onto the thinnest sheets of parchment. ${ }^{12}$ Only later, while undertaking the transfer of the Isabella d'Este cartoon, now at the Louvre, did Leonardo create a safeguarding process of the original cartoon by also introducing into the transferral process the use of a secondary cartoon that, once pricked, would be dusted in order to preserve the image depicted on the original cartoon. ${ }^{13}$

The fact that the two drawings of the Codex Atlanticus are, however, a third version of Leonardo's original drawing is confirmed by two considerations: They are not pricked and thus are not secondary cartoons, whereas, on the other hand, they bear the very same measurements as the drawings carried out in the two codices of De divina proportione. The measurements of the two bodies on ff. 263 r-c [708 r] and 263 r-b [707 r] of the Codex Atlanticus coincide exactly with the measurements of the bodies in the Ambrosiana Codex: the first is $119 \mathrm{~mm}$ high $\times 123 \mathrm{~mm}$ wide, the second $120 \mathrm{~mm} \times 123 \mathrm{~mm}$. These measurements correspond to the images of the two bodies XxIX and $\mathrm{xxx}$ of the Ambrosiana Codex: $119 \times 122 \mathrm{~mm}$ and $120 \times 123 \mathrm{~mm}$, respectively. The difference of $1 \mathrm{~mm}$ appears to be irrelevant in the first case, while the measurements of the corresponding bodies in the Geneva Codex (measured however from the

\footnotetext{
12 The parchment of the Geneva Codex is both highly transparent and exceptionally fine, so much as to allow the tracing of a drawing underneath, as kindly stated by Isabella Fiorentini and Marzia Pontone to me (oral communication).

See Ames Lewis, Isabella and Leonardo, 126.
} 
facsimile) indicate, for XXIX, $120.5 \times 122 \mathrm{~mm}$, and for XXX, $120 \mathrm{~mm} \times 122 \mathrm{~mm}$, the almost precise correspondence of the measurements, except for the very slightest distortions due perhaps to procedures related to the photographic reproduction of the facsimile. However, this is not all. Even the woodcuts of the printed edition of 1509 , in which the different transitions from the primary (original) drawing - to the reproduced drawing, and thence to the engraving plate, and finally to the printed version-obviously entail dimensional shifting. These turn out to be of similar measurements to those of the drawings of the Codex Atlanticus: $116 \times 121.5 \mathrm{~mm}$ in the case of the full body (XXIX), and 120 $\times 126 \mathrm{~mm}$ for the hollow body (xxx). This confirms the proliferation of the trace changes and the steady departure from the original drawings. In the case of the measurements of the bodies in the 1509 edition, it must be noted that the point of view chosen for the engraving of the body numbered XxIX is different from the one, strictly frontal, that characterizes the two illustrations of the two codices. The Dodecaedron abscissum solidum is presented to be slightly turning to the right so as to show the faces of the lateral pentagons in a different perspective light and yet the lower pentagon is shown, which is totally lacking in the watercolor drawings of the two manuscript versions. If this were true (another possibility is to imagine a light rotation of the drawing in the process to produce the woodcut), it would suggest the existence of original drawings taken from different points of view that were different again from those used for the two manuscript versions.

If the almost perfect alignment of measurements in the Milan and Geneva bodies with the two drawings of the Codex Atlanticus were to verify the hypothesis that these latter ones were used as tracers, or cartoons, of the first ones, then this technical evidence provides for an alternative proposal. Both in the drawings of the Milan Codex (as on the body illustrated on f. $102 \mathrm{r}$ (table XXII, Ycocedron Planvs Vacvvs) and in the bodies drawn in the Geneva Codex, noticeable traces of pouncing dust spots-after joined by pen strokes-appear beneath the very finely inked outlines at the edges of the body. In the particular case of plate number Xxx in the Geneva copy there are traces of dust spots, as may be clearly seen in the photographic enlargement published here (Fig. 5.7). We may therefore attempt a reconstruction of the sequences in the lengthy planning and working process at the very origin of the image production — the "packaging" we might see — of the platonic bodies that accompany the texts present in the Milan and Geneva versions of Pacioli's work.

As Kemp has demonstrated, Leonardo's use of the perspective "net" for the graphic production of the bodies in the original drawings, ${ }^{14}$ which would lead

14 See Kemp, The Science of Art, 171 (italian edition, 191). 


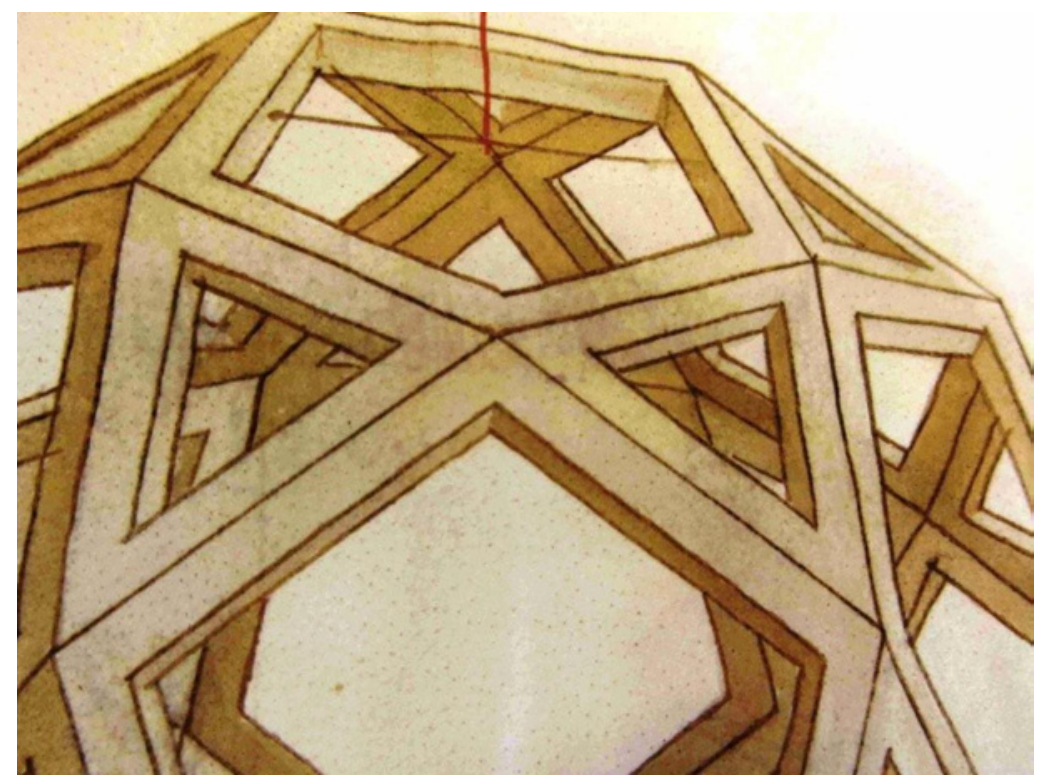

FIGURE 5.7 Detail of Figure 5.6 (enlarged).

one to presume that there were platonic bodies in a preexisting three-dimensional version that Leonardo was supposed to have drawn through the "veil" (or checked net) in perspective. The procedure is shown by Leonardo himself in the famous drawing that appears on f. 1 bis $r-a$ [ $5 \mathrm{r}$ ] of the Codex Atlanticus where the artist depicted an armillary sphere shown through a veil. ${ }^{15}$ This would explain why traces of Leonardo's drawings with diagrams of the perspective and geometric construction of bodies do not exist, since they would have been of considerable complexity and difficulty. ${ }^{16}$ In substance, Leonardo

Concerning this drawing see Carlo Pedretti, The Codex Atlanticus of Leonardo da Vinci. A Catalogue of Its Newly Restored Sheets. Part One. Volumes I-VI (New York, Johnson Reprint Corporation-Harcourt Brace Jovanovich, 1978), 25, that dates it to "ca. 1480-82". Martin Kemp The Science of Art, 171) dates it instead to "ca. 1510." I agree obviously with Carlo Pedretti on the older date of the drawing. On that drawing see now Pietro C. Marani, L'occhio di Leonardo. Studi di ottica e prospettiva. Disegni di Leonardo dal Codice Atlantico (Novara: De Agostini, 2014), 41-43 [dating 1480-1482 (and 149o?)]; and Marco Versiero, in Leonardo 1452-1519. The Design of the World, exh. cat., Milan, Palazzo Reale, 16 April-19 July, eds. Pietro C. Marani and Maria Teresa Fiorio (Milan-Geneva: Skira, 2015), 518.

16 Such drawings exist however in the Codex Atlanticus, for example on f. 263 r-a [706 r], that depicts a study for a solid body with concave sides (not a "water wheel"), pricked in order to create a perfectly symmetrical half (Bambach, Drawing and Painting, 172, and the long n. 156, 434; Versiero, Codex Atlanticus, 148) that however Carlo Pedretti does not 
must have painted from real life the sixty three-dimensional bodies prepared by someone else, that is by Pacioli himself. Indeed, the latter claimed in chapter LXX of his Divina proportione:

Commo se habino retrovare tutti li dicti corpi ordinatamente commo sonno posti in questo facti in prospectiva; e anchora le lor forme materiali secondo la lor tavola particulare posta patente in publico. Capitulo LXX. Perché dove non è ordine sempre fia confusione, però a più piena intelligentia de questo nostro compendio, per saper retrovare tutte le proprie figure in prospectivo aspecto in questo sequente poste e ancho le materiali secondo lor publica tavola, la vostra celsitudine observarà questo modo: cioè, quando legiarete di sopra in lor capitoli de lor creationi e formationi, guardarete in quel luogo, da rimpecto in la margine del libro, el numero segnato per aboco antico, cioè così comenzando dal primo al $48^{\circ}$ capitulo, dicendo .I.II.III.IIII.v. e sequendo fine a lor termine. E quel medesimo numero aponto, farete de trovare de sotto dove in questo dicti corpi sonno per ordine tutti figurati; el qual numero similmente, in quel luogho in margine sirà posto referendo .I. a .I. e .II. a .II. e .III. a .III. e così in tutti. E quella tal figura sirà del dicto corpo facto in piano con tutta perfectione de prospectiva, commo sa el nostro Lionardo Vinci. E questi medesimi numeri anchora recercarete fra le forme materiali de' dicti corpi pendenti con lor nome in greco e in latino, posti in un breve sopra ciascuno afixo nel suo cordiglio fra doi ambre negre, pur referendo ognuno, commo è dicto, al numero posto in margine dove di quel tal se tracta. E vostra celsitudine a l'uno e a l'altro modo harà loro dispositioni, le quali non de vil materia_commo per inopia a me è stato forza - ma de precioso metallo e fine gemme meritarieno essere ornati. Ma la vostra celsitudine considerarà lo affecto e l'animo nel suo perpetuo servo. $^{17}$

Pacioli had therefore made beforehand his bodies in "vil materia" — perhaps in wood or cardboard - much before 1498, and therefore being in Milan (it is un-

consider to be authentic (Pedretti, The Codex Atlanticus, 2:82), but belonging to a group of exercises on "mazzocchi" (of which the Codex Atlanticus was also part, ff. $261 \mathrm{v}-\mathrm{a}$ [702 r], 261 v-b [703 r], and 225 v-a [613 r]: Pedretti, The Codex Atlanticus, 1:79-80) attributed by him to Francesco Melzi. Like Bambach I believe however (Bambach, Drawing and Painting, n. 156, 434) that the drawing of the pointed circular solid on the Codex Atlanticus, f. $263 \mathrm{r}-\mathrm{a}[706 \mathrm{r}$ ], is by Leonardo.

See Ms. Ambrosiano, sheets LXXXIII-LXXXIIII. 
likely that he had made them earlier, and thus even before his arrival in Milan), it was Leonardo who was able to draw them in perspective. It is unusual — and credit must be granted to Carlo Pedretti for this assumption - that Luca Pacioli copied anew all the platonic bodies for the Florentine Republic since he had donated them to the latter in June 1504. This event coincided with Leonardo's works for the Battaglia d'Anghiari, which confers upon the platonic drawings as high a level of political propaganda as the Battaglia d'Anghiari and Michelangelo's Battaglia di Cascina, "in quanto Platone stesso avrebbe eletto il dodecaedro a simbolo del buon governo."18

The next step, after Leonardo had undertaken the perspective drawings from real life, would have been the packaging of the cartoons, achieved by pricking the actual originals, possibly giving rise to small controcartoni or cartonetti that were obtained thanks to the pricking of the originals. These would most definitely include the two aforementioned drawings in the Codex Atlanticus, ff. 263 r-b [707 r] and 263 r-c [708 r]. One of Leonardo's assistants was probably responsible for their execution, or even Luca Pacioli himself. ${ }^{19}$ The guidelines for the completion of some of the watercolor drawings in both the Milan Codex and the Geneva Codex most probably originated from these pricked cartoons, given the visible traces of pouncing dust on some of them. Quite possibly, considering the exceptional transparency of the Geneva parchment sheets, it is also feasible that the pen-and-ink drawings-after monochrome watercolour is added (they also perhaps look closer chromatically to wooden prototypes or to the cardboard models made by Pacioli, as suggested

See Carlo Pedretti, "Leonardo, 1505 e dopo," in La mente di Leonardo. Al tempo della 'Battaglia d'Anghiari,' exh. cat., Florence, Gabinetto Disegni e Stampe degli Uffizi, 3 October7 January 2007, ed. Carlo Pedretti (Florence: Giunti, 2006), 27. The mention of the payment to Luca Pacioli of $5^{2}$ ducats and 9 soldi "per più spese fatte in più corpi geometrici, cioè di geometria" is associated with payments made to Leonardo for the expenses relating to the painting of the Battaglia d'Anghiari, in the famous document of 30 June 1504; however, the passage relating to Pacioli has always been omitted by the transcribers. The part regarding Pacioli has been omitted both by Carlo Vecce, Leonardo (Rome: Salerno Editrice, 1998), 239-240; and by Edoardo Villata, Leonardo da Vinci: I documenti e le testimonianze contemporanee (Milan: Ente Raccolta Vinciana, 1999), 172, doc. no. 194.

19 The hand of Luca Pacioli was perhaps responsible for at least one of the geometrical drawings kept in the Codex Atlanticus, f. 198 r-b [533 r], according to a recent suggestion by Carmen C. Bambach accepted by Furio Rinaldi: Furio Rinaldi, De ludo geometrico. Disegni di geometria e matematica dal Codice Atlantico, exh. cat., Milan, Biblioteca Ambrosiana, 8 November 2013-7 January 2014 (Novara: De Agostini, 2013), Introduction. That drawing is very similar to the geometrical drawings that run along the text in the De divina proportione manuscript kept in the Ambrosiana Library, drawn probably by Pacioli himself. 
by Marzia Pontone) — were achieved by re-tracing a cartonetto placed beneath the actual parchment sheets. That many of the lines bordering the edges and sides of the various bodies appear (in the Geneva Codex) to have been drafted by hand without the aid of a ruler, seems to confirm this re-tracing. As hinted at the beginning of this essay, there remains the possibility that Leonardo may have intervened during these particular operations, as in the case of the Ambrosiana Codex, to undertake the "painted" finish of some of the regular bodies, namely those already mentioned as the finest quality and perhaps carried out by a left hand.

A final problem concerns the sequence of the text layout in the execution of the two surviving versions. Studies carried out by Marzia Pontone, including a careful reading of the text by the copyist Lorenzi, would appear to solve the issue by assigning precedence to the Geneva Codex over the Milan Codex. However, I have no doubt about the better quality of the illustrations in the latter and their precedence over the Geneva ones. One clear example offers proof: The top side of the upper pentagon in the Geneva Codex (body XXVIIII, Fig. 5.5) is not perfectly horizontal (since it was drawn by hand), perhaps due to a slight slipping of the cartonetto, while the corresponding one in the Milan Codex (Xxix body, see Fig. 5.3) is almost perfectly horizontal. However, the same inclination may also be found (once it has been turned around) in the drawing of the Codex Atlanticus f. $263 \mathrm{r}$-c [708 r]. It is therefore also possible that the artist of the Ambrosiana Codex also corrected what could have appeared to be an erroneous perspective in the drawing of the Geneva Codex. 